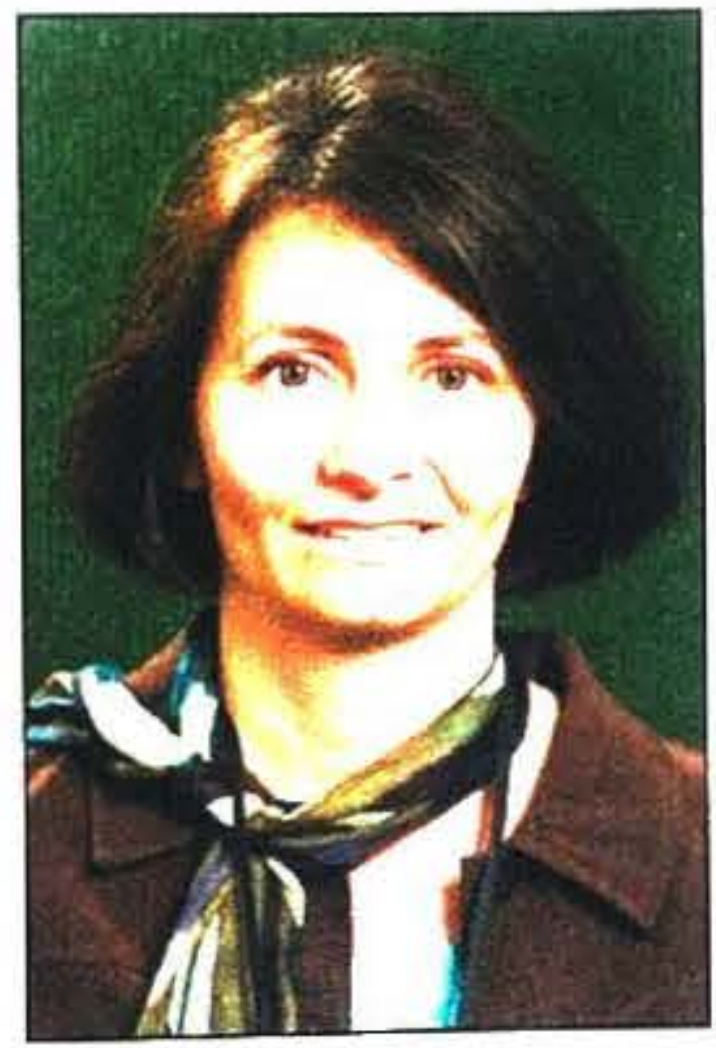

\title{
CAN WOMEN'S STRUCTURES \\ HELP NEW ZEALAND AND \\ UNITED KINGDOM UNION \\ REVIVAL?
}

\author{
Jane Parker \\ Department of Management \\ Auckland University of Technology
}

Union decline in the UK and NZ is a familiar story. Drawing on NZ research and an advanced UK project involving two national surveys, interviews and documentary evidence, this paper examines the relationship between union women's structures and union revival efforts. It emerges that, mediated by context, women's structures contribute to revival strategies, not just in terms of quantitative and external outcomes, but in the qualitative processes of engaging members. Findings inform a discussion of future directions for revival strategies and gauges of union vitality.

\section{Introduction}

TUC affiliate membership in the UK almost halved by the mid-1990s from a peak of 12.2 million in 1980 , with losses concentrated in male-dominated, private manufacturing against a backdrop of mass unemployment, privatisation and de-industrialisation. Further pressures were introduced by globalisation and Labour's reluctance to reverse Tory anti-union legislation, despite recent employment growth. Between 1991-94, NZ membership also almost halved, from 600,000 . Decline was concentrated in private and mixed/non-profit sectors, and attributed to the ECA 1991, under which unions were 'no longer creatures of the state' (Crawford \& Walsh 1999). Economic liberalisation and welfare cuts added to union officials' workloads and increased union amalgamations. Subsequent decline is linked more to "within-group behavioural changes' (Charlwood \& Haynes 2008).

TUC affiliate membership recently stabilised at 6.5 million while NZ numbers have grown modestly to 373,327 (DoL 2008), partly reflecting the introduction of some union protections. However, analyses of union renewal efforts concur that sustained growth is not certain in either country. And while UK and NZ unions have been influenced by organising models, they have charted their own courses of renewal, signalling the perceived crisis and institutional, economic and political terrain. Concomitantly, an academic focus on union women's structures (WS) (e.g. women's committees, conferences, courses, networks) has shifted from their equality implications to their meaning for union revival. This paper compares WS-renewal relations in UK and NZ unions. Findings inform a discussion of future revival efforts and union 'health' indicators.

\section{Union revival strategies}

\section{Organising/recruiting}

These activities are natural union priorities, but more recent is the adoption of a US-style organising model. The UK TUC launched its New Unionism project in 1996 to promote a return to grass-roots involvement, and the Organising Academy in 1998. NZ's CTU ran workshops and seminars in 1994 in a climate of contraction, and has encouraged affiliates to adopt new methods of mobilising members. In both countries, changing union official profiles have also shaped organising strategies.

However, it remains difficult to identify a significant UK 'organising union' and membership leaks have proved difficult to plug by organising in new sectors/workplaces (Machin 2000); most organising and recruiting aims at consolidation (cf. revitalisation) (Heery et al. 2003). NZ organising efforts have often been constrained by small union size, isolated initiatives in fast-growing sectors, and debate over resource allocation. Both countries' unions have also experienced employer opposition. activist burnout and staff resistance to a culture shift. Oxenbridge (2000) also noted that the CTU had not been very dynamic about promoting activist organising but it established an Organising Centre in 2000, and 2005 Conference delegates pledged to increase activity to rebuild union density, organising, capacity and power.

\section{Partnership}

Since 1997, the UK Government has promoted labourmanagement partnerships which emphasise workplacelevel cooperation, and provided financial support through a Partnership at Work Fund. The TUC responded with a Partnership Institute which advises employers and unions. In NZ, union-management partnerships are considered anecdotally to be uncommon 
but the CTU wants affiliates to engage as a legitimate partner in industry. A Partnership Resource Centre (PRC) within the DoL was established in 2004; its Steering Committee comprises CTU and employer reps. The ERA 2000 and amendments emphasise productive employment relations (ER) based on 'good faith' behaviour and bargaining, with conflict resolved primarily via mediation. However, the Act is not a 'magic bullet' that organises workers into unions and collective bargaining units (Wilson 2000).

Partnership estimates in the UK vary greatly. However, assessments of their impacts on union membership and bargaining power are generally negative (e.g. Kelly 2004). A PRC (2006) survey found that one-third of employers, including a minority in the public sector (despite the assistance of the Partnership for Quality initiative), had a workplace partnership with a union; the same percentage showed interest in such. Partnerships were employed selectively and in a pragmatic, sometimes experimental/non-committed, way. Although union officials saw partnering as beneficial for members and employers, it is unclear whether their assessment concerned membership change.

\section{Restructuring}

Union mergers, mainly involving smaller unions' absorption into larger unions, have been significant in both countries. Many have been defensive, driven by membership decline and associated financial weakness. TUC affiliates dropped from 112 in 1979 to 58 by 2006. In NZ, the ECA and LRA 1987 with its ' 1.000 minimum membership' rule contributed to a fall in registered unions from 223 in 1985 to 80 by 1991 though this included disaffiliations due to the CTU's unwillingness to strongly challenge the ECA (Harbridge \& Honeybone 1996). While some larger unions extended their membership via mergers and recruiting, overall, mergers have impacted little on union density and performance (Michelson 2000) and CTU campaigns for union restructuring along industrial lines have been largely unsuccessful.

Internal restructuring has been partly designed to assist renewal efforts, in political terms by enhancing union representation of member diversity and thus organising capacity. Administrative changes have stressed efficiency, new management techniques and budgetary control (e.g. targeting potential member groups; using etechnology and taskgroups) but have not reduced union bureaucracy or increased membership significantly.

\section{Political engagement}

UK unions have had a stronger political voice under Labour which has delivered gains (e.g. a national minimum wage, transposition of EU law such as that governing working time). However, much of this has been cautious for Labour to maintain its pro-business face, and laws on industrial action and statutory union recognition are limited. Despite some gains, the labour movement has been unable to position itself as a major political actor with whom the Government must interact despite the increasing significance of lobbying in the policy-making process, and its contribution to Party funding.

Although unable to exert much influence over National's policies, the CTU has tried to embark on an active programme with Labour-Alliance. Its 2007 political strategy is seen as an 'unequivocal signal that there is a greater role for unions in politics' (Kelly 2007). The Government also involves social partners in industrial/labour market policy via consultative and tripartite schemes (e.g. PRC). As McLaughlin (2007) observes, though, without a solid institutional framework, such developments depend on the continued support of union movement leadership and peak employers' associations, and on Labour's continued electoral success, complicating prognoses for union membership.

\section{Alliances}

Both movements' coalitions have typically been confined to political dialogue, and recently for some unions, partnerships. Increasingly relevant are civil alliances. On one hand, unions' internationalism is under-developed in practice. UK community unionism has been described as involving ad hoc responses to community-based threats, and it has not widespread in NZ (Peetz 2006). On the other, the CTU intends to be part of a social movement unionism to build a political constituency for social justice. Research suggests that, while civil alliances are neither the TUC nor affiliates' focus, their interest in such continues to grow, and monitored alliances have impacted positively if modestly on union influence (Parker 2008).

Union decline prompts reinvigoration efforts, amid varying institutional and environmental conditions. Strategy 'mixes' employed by UK and NZ unions have helped stave off further decline rather than contributed substantially to membership growth. However, revival is not merely about quantitative outcomes as evidenced by internal restructuring.

\section{WS and union revival}

Union WS development has attracted opposition and been encouraged by second wave feminism, industrialisation and reform of union culture in the 1970s. Other external developments (e.g. limited positive provisions of the UK Sex Discrimination Act 1975) also reflected growing rejection of an assumed level playing field' for women and men seeking to enter and progress within organisations, providing a springboard for union initiatives. Sensitivity to women and potential members' interests and attempts to deliver them became part of many unions' declared strategy to counter male membership decline in the $1980 \mathrm{~s}-90 \mathrm{~s}$. 
WS growth in UK unions slowed in the 1980s in a context of persistent unemployment which helped prioritise (men's) 'mainstream' concerns; the likelihood of advancing beyond formal equality in these circumstances was small. Evidence is mixed on more recent WS numbers. Parker (2006) recorded ongoing increases but the TUC (2007) suggests that national women's committees (NWCs) in large unions have fallen off. Smaller decline in the percentage of unions with disabled and LGBT national committees indicates that they are now more widespread than NWCs, stressing a trend towards greater union activity on their part and coinciding with anti-discrimination laws on these issues.

The number of particular WS forms in NZ unions has also fluctuated. CTU's Women's Council lay dormant for most of the 1990s but now holds meetings, courses and a biennial conference. Among unions, NDU WS disappeared with the ECA's arrival but, as in other transport unions, were recently revamped in response to growing female membership. Some also detected a backlash against the feminisation of unionism during the 1980s-90s' union amalgamations. However, Nolan \& Ryan (2003) assert that while WS in certain unions waned at times, separatist structures generally flourished in the 1980s. However, as in the UK. WS also influenced or started to 'compete' with organising around ethnicity, sexuality, disability and class. Arguably, by the 1990s, 'some women had gone beyond the separatist phase. At the least, separatism was a necessary phase ... [and there is a] need for vigilance over gains made'. Many of their female interviewees cited the organising model to explain why women continued to make gains in union representation despite growing union size and workloads, and WS losses but in both countries, identitybased organising also emerged as part of union efforts to grow and mobilise membership (e.g. Flynn et al. 2004).

Despite certain WS changing fortunes, they remain a widespread form of identity-based organising in UK unions (Parker 2006), and although less common, feature in a substantial minority of $\mathrm{NZ}$ unions. An HRC gender audit for its 2006 Census of Women's Participation found that, of 27 of 33 survey respondent affiliates, seven had an active WS (HRC 2008). The method described next was used to study WS' meaning for union revival strategies.

\section{Method}

For the UK, a survey in 2004 sought an official response from 71 TUC affiliates about the presence of WS. At least' 142 WS across 27 of 56 responding unions were identified (Appendix Table 1). A second survey in 2005 went to equality officers, reps and activists in unions with WS to canvass views about WS influence on union renewal. Forty-six respondents from eight affiliates commented on at least 18 WS. Semi-structured interviews with 25 respondents and union contacts also facilitated access to documentary sources.
$\mathrm{NZ}$ official/CTU and union websites and documents were examined in 2008 for comparable data. At least 31 WS were identified across nine unions (Appendix table 2), slightly more than indicated by HRC (2008). Although a smaller total than for UK unions, pro rata, the difference is less pronounced. NZ union WS span similar forms to those found in UK unions but it was difficult to discern their relative 'popularity' given smaller numbers. Thematic analysis of WS data was structured according to revival strategy 'types', and each of these dimensions underpinned by constructs from data and literature to assess whether WS contribute to or modify the strategies.

\section{Findings}

\section{Organising/recruiting}

Most of at least 62 WS in 24 UK unions were conceived almost as much as part of recognised union organising strategy as a response to growing rank-and-file consciousness of serving (women's) members interests better via special representation. Organising and representation/internal reform strategy were almost equally cited as the rationale for establishing many women's committees, conferences and task groups, while women's courses and networks were noted for supporting organising efforts. WS, particularly committees and working groups, also lend support to union conventions that are partly concerned with organising/recruiting. PCS Women's Advisory Committees' (WACs) 'meeting at Group conference helps networking, and supports new women delegates, particularly from smaller branches' (WAC member). Many WS saw the importance of recruiting, organising and income generation for union vibrancy, with experienced union women sometimes mentoring new women on union procedure.

Decentralisation of collective bargaining in UK has also raised some WS' profile. PCS hosts a growing number of branch WACs with close links to local union organising drives. In USDAW, a senior FTO felt that such activity encouraged a greater sense of union 'ownership' among female members - vital given the retail sector's high labour and member turnover. TSSA's regional 'Women in Focus' (WiF) committee network 'genders' local organising initiatives by encouraging women to attend small union groupings at their homes to overcome logistical/domestic obstacles to participation.

As well as directly augmenting union organising, WS also contribute to it via issues they raise to union platforms. While several senior officials noted WS' varied success in having their union prioritise or even address their interests, first survey respondents indicated that for at least 91 WS across 14 affiliates, the range of concerns raised to national agenda/negotiations had increased. Just over half (in eight unions) perceived that several issues (e.g. equal/low pay) have become priorities. 
UK WS were often seen as contributing to union recruitment via direct and supportive action, with local WS well placed in this respect. TSSA's WiF network assessed that WiF groups have 'made real progress in ensuring that [TSSA] continues to grow' but noted 'the need ... to continue to invest adequate resources'. As with organising, WS also helped feminise elements of recruiting processes, and sometimes their outcomes. USDAW's Divisional Women's Committees (DWCs) combine meetings with workplace 'walkabouts' to access employees. The predominance of women in many of these workplaces (e.g. supermarkets) means that 'like by like' recruiting and organising occurs. Informants did not discuss WS contributions to union organising and recruiting in relation to recognition deals, suggesting that WS are best contribute where the union is established.

Similar involvement in union recruiting/organising was revealed for many NZ union WS. Transport unions have sought to organise, train and encourage women members; active involvement, and establish WS and international ties. NDU's 'Women and workplace issues' course aims to empower women workers to become involved in the institutions and processes that impact on their working lives. Similarly, its 'Issues for women working in a male-dominated environment' workshop sets an organising task for participants, its 'Leadership development for women workers' course provides them with the skills for union leadership and to develop strategies to better involve women. A 2007 MUNZ women's educational encouraged one attendee to organise her workplace into a committee for job-related issues. NDU regional women's committees are represented on its Regional Organising Committee (NDU 2007). In the public sector, the heavily femalepopulated NZNO Women's Health Section recruits nurses and supports NZNO objectives, policy and activities (NZNO 2005). Qualified SFWU women run regional seminars for women members and delegates to help them improve their confidence and develop skills in representing and organising women workers.

WS organising is commencing in several unions. PPTA's new National Women's Network (NWN) of Regional Women Coordinators (RWCs) prepares women for union positions, supports women's networks and participates in ERE programmes. Its Women's Hui provides another organising opportunity (PPTA 2008). WS organising is planned elsewhere. ASTE-AUS' amalgamation will see national and local women's committees in place by April 2009. The former will organise women members at branch level and ensure that the Union represents women's interests at policy and industrial level. Further, certain unions without WS participate at external WS (e.g. the Australasian Women Police Conference, attended by NZPA women, addresses low female participation in police unions and has proposed an industrial network between women in different police unions.
WS organising around diversity is growing, especially in relation to internal union governance. NZEI's Women's Network addresses issues for Maori and Pasifika women, and women of colour. PPTA NWN members, in the case of Te Huarahi and Komiti Pasifika, build women's networks from their structures and run joint regional events. NDU seminars for Maori, Pacific Island and women workers help attendees to identify and pursue ER and union governance issues of concern to them.

\section{Partnership}

UK informants did not relate WS activity to partnership arrangements but this link was made for several NZ union WS, reflecting wider emphasis on trust-based ER. SFWU regional women's seminars topics include 'good faith' principles and the ERA. For the movement, Dyson (MWA) stressed gender-partnership links at the 2005 CTU Biennial for Women, noting the ERA's importance for 'requiring parties to ER to deal with each other in good faith. This is very important to pay and employment equity'. She also referred to the first fiveyear Action Plan for NZ women launched in 2004 to improve their circumstances: 'We will continue to ... address the barriers that still hinder working women from achieving their full potential. The CTU [and others] is an important partner in that process'.

\section{Restructuring}

Union mergers and amalgamations were shown to encourage the introduction of or reforms to WS. In the UK, a Community national secretary wrote that its formation from ISTC-KFAT's merger supported WS' arrival. PCS' formation via mergers in 1998 similarly led to a re-organisation, with new structures including WS. By contrast, former GPMU respondents were concerned that the imminent merger with $\mathrm{Amicus}^{2}$ would not involve the transfer of its WS, thereby 'squeezing' women from union posts. This was averted in PCS via a 'softening' of WS' formal status to reduce potential opposition to their continuation. In NZ, too, restructuring has impacted variously on WS activity (as noted with ASTE-AUS).

UK evidence revealed that WS have also furthered internal union reorganisation by injecting 'new' or different (democratic) principles into certain processes and structures. This development was often linked to the decentralisation of union decision-making procedures, supporting the introduction of local WS (e.g. in PCS and TSSA). A number of WS have also become increasingly 'institutionalised' within their union. The first survey found that nearly all of 19 well-established WS were incorporated via union constitutions, helping them access union resources. However, only four make policy, and most of at least 27 WS in 16 unions have advisory status only. Formal inclusion of WS at national level sometimes led to the introduction of more local structures (e.g. TSSA's national WiF was part of the catalyst for regional WiFs which 'enable more women to become active within the union' - WiF member). In NZ, WS 
formalisation and impact on internal restructuring/organising were observed in several unions. NZNO's Gynaecology Nurses' Interest Group was formalised at its inaugural conference in 2002 before becoming a NZNO section in 2004. One of its aims was to establish networks for nurses.

First survey data showed that for at least 74 WS in 25 UK unions, their most common union-centred pursuits were: women's union representation; union organising and participation by women; and changes to structures and procedures to assist women's union access. Widelyheld perceptions of WS' inclusive and less procedural ways of working also led some to see them as a facilitator in this regard. NZ union WS' union-related pursuits were similar. And by raising women's interests and helping women to better engage with union channels, WS were seen as vehicles for advancing union revival. Perceived 'spillover effects' as WS members advanced into the mainstream and as some union bodies applied 'WS approaches' (e.g. rotating positions, lateral networking) included increased member mobilisation, and procedural efficiency. While NZ data yielded few insights into WS' internal workings, their common emphasis (particularly locally) on developing women's confidence to operate effectively in unions could infer that WS are likely to provide a relatively relaxed space for such activity.

\section{Political engagement}

In both countries, union WS' political engagement varies. Following the 2005 CTU Women's Biennial conference. Secretary Beaumont noted the 'dynamic women who worked hard to develop ways of continuing to build our industrial and political power for our families and communities'. Union women's conferences. committees and courses were most likely to consider union and/or women's engagement with external political processes. NDU's 'Issues for women ...' course assists attendees to better understand workplace ER structures and processes. PPTA's Regional Women's Coordinator works with NWN members on the political and union education of, and explains PPTA policies to. women members. In 2008, NWN was involved in the Pay and Employment Equity Review of Schools. However, the extent to which calls for greater union input into political processes within a more pro-union industrial relations context (Haworth et al. (2006) even describe the development of a wider social democratic model) translates WS activity is unknown.

Although UK unions have given more support to their Government than they have received, TUC and Labour Party Conferences passed resolutions in 2005 calling for the repeal of anti-union laws and introduction of a TU Freedom Bill. Some see this as a step towards introducing balance of power in the workplace. WS within the TUC. affiliates, trades councils and others have supported the Bill but informants did not refer directly to the meaning of political engagement for union influence and growth.

\section{Alliances}

UK data showed that many WS have become increasingly interested or involved in networking and civil alliances. This development has occurred as a matter of policy and in order to offer practical help around issues like domestic violence and refugees within local communities. PCS interviewees told how their WS conceive of themselves as constituent parts of a larger women's network within and beyond the union so it seemed natural for them to establish relationships with bodies such as Women's Aid and Refuge. TSSA WS campaign with the National Childminding Association, and women's health and safety organisations. Drug and youth crime were also common community concerns that saw WS link with local activist and state rehabilitation schemes. Stressing WS' relative independence, an exWGGB member recalled that her union could not formally support miners during the 1984 strike because of its non-political status and 'Thatcherite members' opposition' but its NWC contacted miners' wives and collected money to help their families survive.

It was difficult to establish the scale of NZ union WS' civil alliances, stressing the need for further research. However, several unions posted information (e.g. PPTA NWN members work with Women's and Field Officers to strengthen unionism in secondary schools, and the WO works with other women's organisations and unions on women members' issues, particularly through work with the CTU Women's Council).

Some NZ sources revealed WS networks within unions, with CTU WS and beyond. As in the UK, many NZ unions (with/without internal WS), CTU identity groups and individual women activists and officers partake in workplace- and other-centred campaigns with political structures, trades councils and international groups/movements (e.g. Greenpeace, Cuba Solidarity, AI). CTU's 'Union women in Action' course expects attendees to develop skills to explore the issues that affect women workers, describe key processes for change and democracy within their workplaces, unions and communities, plus confidently participate in a process most relevant to them.

WS' external links reportedly increased in about half of UK unions with WS, supporting claims that a 'new generation' of union reps are encouraging understanding of the need for union involvement in civil alliances. Most informants perceived that the direct impact of such on union revival was difficult to assess, and it was not necessarily the purpose of all alliance-building. A number of WS contain their coalition activity, due to resource constraints but also to 'focus on what they do well'. Prior to merging with Amicus, a NWC respondent stressed how GPMU WS tried to "consolidate and build 
on previous work, trying to ensure that new people are involved [and] to strengthen equality networks'.

However, alliances were seen as educational and empowering for those involved, with implications for union vitality. A TSSA WiF member commented: 'WiF've given members more confidence in their own ideas, and introduced people who'd normally never have got involved in the wider women's movement ... Our external links are strengthening, helping WiF to grow'. The potential for union organising was stressed: "[at the 2005 TUC Women's Conference] we learnt from women in other unions and TUC about attracting and mobilising women in group activities' (PCS NWF member).

\section{Conclusions and areas for future research}

UK and NZ union WS are regarded by insiders to contribute to union revival efforts via organising, recruiting and internal reform. While difficult to quantify their influence, the much larger number of UK WS might suggest a greater aggregate impact. WS are also seen as conduits for disseminating gender/diversity consciousness and providing effective voice for neglected constituencies. Indeed, unions may learn from WS ways of organising, sometimes marked by an adaptability and grass-roots responsiveness that is less alienating than certain union procedures. Many WS develop external links, presenting opportunities for their unions to benefit from closer environmental links and responding to growing concern about the scope of union purpose, conventionally conceived. Informants felt that a broader, socio-political role would work to strengthen union operations. Although WS in a number of UK and NZ unions are also concerned with political engagement, as at union level, there is scope for considerably more activity.

The perceived absence of connection between UK union WS and partnerships contrasts with explicit links for certain NZ WS. This, and the non-involvement of UK WS in recognition deals, may reflect a 'limited return' expectation, views that partnerships/recognition only concern national union officers/structures or other factors - the need for research is signalled. Some NZ WS' connection with partnership arrangements may reflect a wider pro-labour shift in policy and legislation, and union activities designed to forge stronger political roles. Yet the meaning of WS' political involvement for union revival remains unknown. NZ data concerned WS intent and practices rather than impacts, though UK impacts on revival could be hard to quantify. One implication is that WS must demonstrate more their worth to their union while unions must consistently monitor WS contribution and help disseminate mutual learning.

Bigger questions are also raised about assessing union vitality. Union organising, recruitment and 'external' restructuring strategies are often measured by changes in membership size/density. Connections with qualitative measures of union strength (e.g. political influence, internal efficiency) are more oblique though UK informants conceived that WS go further than many union structures to accommodate members' circumstances to stimulate their participation. Ultimately, measures of union strength need to reflect their capacity to effect change in all members' lives, and not be limited to gauges of their organisational parameters.

WS emerged as instruments for furthering union revival approaches. They also nuance and encourage changes to strategies and develop ways forward via new/alternative means that stress inclusivity. WS and other equality mechanisms provide lessons for extending underdeveloped union strategies (e.g. via alliances, rethinking 'ways' of working, augmenting membership cohesion). Conventional measures of union vitality focus on quantifiable and overall indicators rather than internal, process-oriented activity, but more comprehensive evaluations of union 'health' might reveal that they are in better shape than often thought. A challenge for unions is to support WS, which both complement and critique their modus operandi; many of those closest to WS in UK unions felt that they could contribute more to union revival, not least due to their widening spheres of interest.

\section{Notes}

1. Conservative estimate due to incomplete subnational WS figures.

2. In 2007, Amicus and TGWU merged to form Unite, the largest UK union.

\section{References}

Beaumont, C. (2005). Speech to NZ Labour Party Congress, Wellington.

Charlwood, A. and Haynes. P. (2008). Union membership decline in NZ, 1990-2002. Journal of Industrial Relations, 50, 87-110.

Crawford, A. and Walsh, P. (1999). No longer creatures of the State: Response of $N Z$ 's Unions to the ECA. Paper, Future of Unions Network Conference, Cardiff University.

DoL (2008). Union Membership 2008, Wellington: DoL.

Flynn, M., Brewster, C., Smith, R. and Rigby, M. (2004). Trade union democracy: the dynamics of different forms. In Harcourt, M. and Wood, G. (2004) Trade unions and democracy: Strategies and perspectives. Manchester: MUP. 
Harbridge, R. and Honeybone, A. (1996). External legitimacy of trade unions. Journal of Labor Research, 17, 425-436.

Haworth, N., Rasmussen, E. and Wilson, M. (2007). Collective bargaining, good faith and partnership: New social democratic approaches to industrial relations in NZ. Paper, IIRA Conference, Lima, September.

Heery, E., Kelly, J. and Waddington, J. (2003). Union Revitalization in Britain. European Journal of Industrial Relations, 9, 79-97.

HRC (2008). NZ Census of Women's Participation 2006. Wellington: HRC.

Kelly, H. (2007). Fairness and respect at work: Unions make the difference, speech, CTU Biennial Conference, October.

Kelly, J. (2004). Social partnership arrangements in Britain: labor cooperation and compliance. Industrial Relations, 43, 267-292.

Machin, S. (2000). Union decline in Britain. Discussion Paper 0455, LSE: CEP.

McLaughlin, C. (2007). Challenging the Neo-Liberal Prescription: The Industrial Relations Lessons from Denmark, Ireland and NZ. Paper, fifth International Conference in Commemoration of Marco Biagi, University of Modena.

Michelson, G. (2000). Union mergers: a survey of the literature. Australian Bulletin of Labour, 26, 107 127.

NDU (2007). NDC Rules, (http://ndu.org.nz/rules).

NZNO (2005). WHS Rules, (http://www.nzno.org.nz/Site/Sections/Womens Health/default.aspx\#29835-1).

Nolan, M. and Ryan, S. (2003). Transforming Unionism by Organising? Examination of the Gender Revolution in NZ Unionism since 1975. Labour History, 84, 89-112.

Oxenbridge, S. (2000). Trade union organising among low-wage service workers: lessons from America and $N Z$. Working paper, Oxford: ESRC CBR.

Parker, J. (2008). TUC and alliances with social movements. Employee Relations, 30, 562-583.

Parker, J. (2006). Towards Equality and Renewal: Women's Groups, Diversity and Democracy in British Unions. Economic and Industrial Democracy, 27, 425-462.
PRC (2006). Illustrated report and stocktake on Workplace Partnership in NZ, Wellington: DoL.

Peetz, D. (2006). Brave new workplace: How individual contracts are changing our jobs. Sydney: Allen \& Unwin.

PPTA (2008). PPTA Women (http://www.ppta.org.nz/index.php/who-arewe/ppta-women?start=3).

TUC (2007). Equality Audit 2007: A statistical report on trade union action on equality, London: TUC.

Wilson, R. (2000). The future of unions in the year 2000. lecture, Massey University (http:www.union.org.nz/search/node/Wilson+200 0+Albany).

\section{Author}

Jane Parker

Senior Lecturer

School of Business - Management

Auckland University of Technology

Private Bag 92006

Auckland 1142

Jane.Parker@aut.ac.nz 


\section{Appendix}

Appendix Table 1: Women's structures by type in TUC affiliates

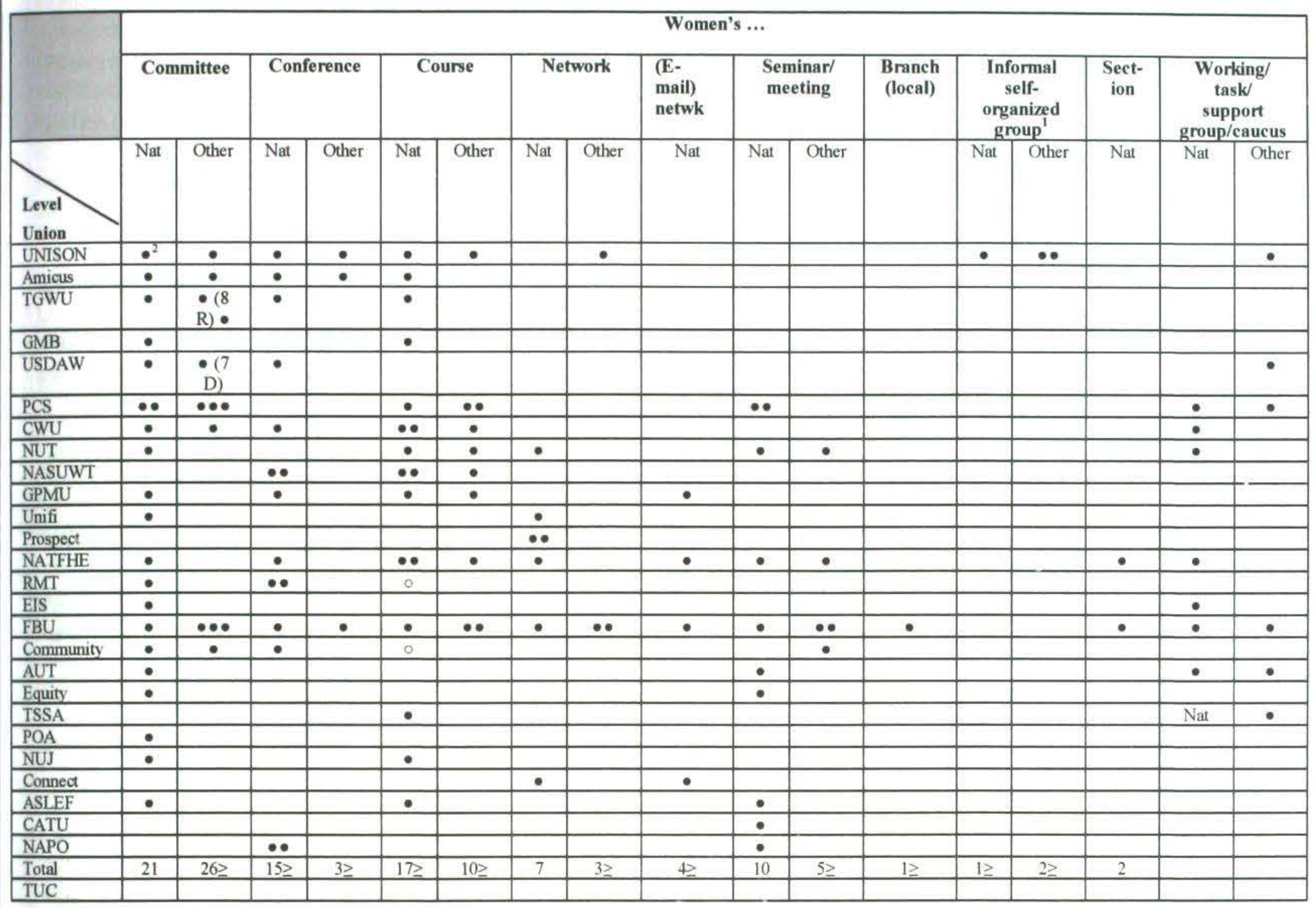

Union $\mathrm{n}=26$, women's structures $\mathrm{n} \geq 142$, where Nat=national, $\mathrm{D}=$ divisional, $\mathrm{R}-$ regional

1 This type of women's structure recorded by the women's structure respondents constitutes the only 'informal form in the sense of not being sanctioned by the 'host union and conducting its activity independently of formal union operations

2 Double or triple dots in a cell indicate more than one women's structure at national level, or more than one at sub-national level A 'hollow' dot indicates a planned

women's structure at the time of the survey

Appendix Table 2: Women's structures by type in NZ unions

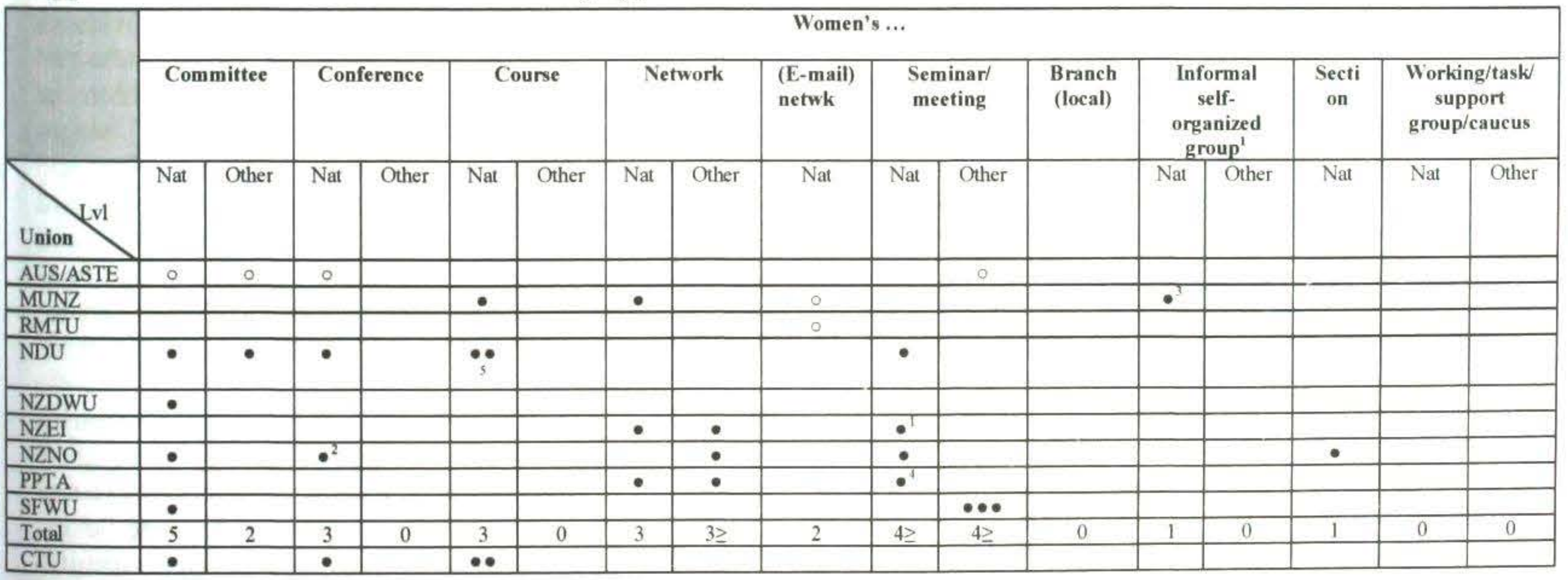

Union $n=9$ (10 if ASTE and AUS are counted separately), women's structures $n \geq 31$, where Nat-national, $D=$ divisional, $R=-$ egional

1 Meeting or hui of the women's network in NZEI

2 Committee, conference, meeting and network of the Women's Health Section of NZNO

3 Women of union's rally for Intemational Women's Day 2005

4 Hui for the women's network

5 A course and a workshop 